\title{
Hoe rechtvaardigheid ook tot rechtsonzekerheid leidt: loyaliteitsaandelen, verleden en toekomst
}

\author{
Prof. mr. H.M. Vletter-van Dorten mr. T.A. Keijzer*
}

\begin{abstract}
In dit artikel bespreken de auteurs de Mediaset-uitspraken van de rechtbank Amsterdam en het gerechtshof Amsterdam, die (onder meer) zien op loyaliteitsaandelen. Hoewel het hof het wat ons betreft bij het juiste eind had, is de onduidelijkheid rondom de eisen die aan de invoering van een loyaliteitsregeling gesteld worden met diens uitspraak wel toegenomen.
\end{abstract}

\section{Inleiding}

In dit artikel bespreken wij de Mediaset-uitspraken van de rechtbank Amsterdam en het gerechtshof Amsterdam, die (onder meer) zien op loyaliteitsaandelen. Zulke aandelen kennen een aandeelhouder voor de lange termijn (feitelijk) meer rechten toe dan een aandeelhouder voor de korte termijn. Dat leidt tot ongelijkheid tussen aandeelhouders en vormt daarmee een heet hangijzer in het corporate governance-debat.

De opzet van onze bijdrage is als volgt. Wij analyseren allereerst het juridische concept van gelijke behandeling van aandeelhouders en de DSM-uitspraak van de Hoge Raad (par. 2). Vervolgens komen de Mediaset-uitspraken aan de orde (par. 3). Aansluitend trekken wij een parallel met de RNA-casus en met name het oordeel van de Ondernemingskamer (hierna: OK) in die zaak (par. 4). Wij sluiten af met een conclusie (par. 5).

\section{Gelijke behandeling van aandeelhouders}

\subsection{De wettelijke regeling van artikel 2:92 BW}

De gelijke behandeling van aandeelhouders vormt het wettelijk uitgangspunt en is neergelegd in artikel 2:92 BW. De strekking van deze bepaling is tweeledig. Allereerst vermeldt

\footnotetext{
Prof. mr. H.M. Vletter-van Dort is hoogleraar Financieel Recht \& Governance aan de Erasmus School of Law (ESL). Mr. T.A. Keijzer is advocaat in Amsterdam, onderzoeker aan de ESL en redacteur van dit tijdschrift.

Mr. T.A. Keijzer was niet op enige (materiële) wijze betrokken bij een van de hier besproken procedures. Beide auteurs schrijven deze bijdrage op persoonlijke titel.
}

artikel 2:92 lid 1 BW dat alle aandelen de houders daarvan gelijke rechten (en verplichtingen) bieden in verhouding tot hun nominale waarde, tenzij de statuten van de vennootschap anders bepalen. ${ }^{1}$ Dit geldt bijvoorbeeld ten aanzien van het winstrecht (waaronder dividend en nader uitgewerkt in art. 2:105 $\mathrm{BW}^{2}$ ) en stemrecht (art. 2:118 $\mathrm{BW}^{3}$ ). Daarnaast bepaalt artikel 2:92 lid 2 BW - dwingend - dat aandeelhouders die zich in gelijke omstandigheden bevinden gelijk behandeld dienen te worden. Daaruit volgt, a contrario, dat aandeelhouders die zich niet in gelijke omstandigheden bevinden niet gelijk behandeld hoeven te worden, naar mate van hun ongelijkheid. Bovendien mogen aandeelhouders die zich in gelijke omstandigheden bevinden ongelijk behandeld worden wanneer daar een objectieve, adequate, noodzakelijke en proportionele rechtvaardiging voor bestaat. ${ }^{4}$

\subsection{De DSM-uitspraak}

Het meest sprekende voorbeeld inzake artikel 2:92 BW is ongetwijfeld de DSM-zaak. Daarin had de vennootschap het voorstel gedaan beleggers die hun stukken ten minste drie jaar hielden een dividendbonus toe te kennen. Het ging dus om een loyaliteitsstructuur, maar wel één die draaide om financiële rechten en niet om zeggenschapsrechten. Hoewel de OK het voorstel van DSM afschoot, ${ }^{5}$ oordeelde de Hoge Raad in

1. Zie Asser/Van Olffen \& Rensen 2-IIa 2019/291-294; P.J. Dortmond, Handboek voor de naamloze en besloten vennootschap, Deventer: Kluwer 2013, par. 186; B.F.J. Assink, Slagter. Compendium ondernemingsrecht, Deventer: Kluwer 2013, par. 31.

2. Waarover B. Bier, Uitkeringen aan aandeelhouders (diss. Rotterdam), Deventer: Kluwer 2003; vgl. ook HR 12 juli 2013, ECLI:NL:HR: 2013:BZ9143, NJ 2013/461 m.nt. Maeijer (VEB/KLM).

3. Zie Asser/Van Solinge \& Nieuwe Weme 2-IIb 2019/76; Dortmond 2013, par. 214-217; Slagter/Assink 2013, par. 45.1-45.3.

4. Hoewel art. 2:92 lid 2 BW zijn oorsprong vindt in het EU-recht en op grond daarvan geldt voor verhogingen en verminderingen van het kapitaal (zie HvJ EG 15 oktober 2009, ECLI:EU:C:2009:626 (Audiolux)), kan de bepaling ook daarbuiten worden toegepast. Vgl. bijv. H.M. Vletter-van Dort, Gelijke behandeling van beleggers bij informatieverstrekking (diss. Utrecht), Deventer: Kluwer 2001.

5. Hof Amsterdam 28 maart 2007, ECLI:NL:GHAMS:2007:BA1717, JOR 2007/118 m.nt. M. Brink; Ondernemingsrecht 2007/138 m.nt. P.M. Storm (DSM). 


\section{Maandblad}

Ondernemingsrecht

cassatie in het belang der wet dat het mogelijk was om houders van een en dezelfde soort aandelen verschillend te behandelen, mits die regeling geen schending opleverde van het in artikel 2:92 lid 2 BW neergelegde gelijkheidsbeginsel. ${ }^{6}$ Een wezenlijk, zo niet het voornaamste element in dat verband leek te zijn of alle aandeelhouders in aanmerking kwamen voor ontvangst van de loyaliteitsbonus. Hoewel de DSMuitspraak zag op een loyaliteitsdividend, werd de zaak regelmatig aangehaald ${ }^{7}$ en ook in de praktijk gebruikt ${ }^{8}$ om te betogen dat het gebruik van loyaliteitsstemrechten was toegestaan. Expliciete jurisprudentie van die strekking was immers niet voorhanden. ${ }^{9}$ De Mediaset-zaak zou daar echter verandering in kunnen brengen.

\section{De Mediaset-uitspraken}

\subsection{Aanloop}

In 2019 kondigde het Italiaanse Mediaset aan te willen fuseren met Mediaset España, waarin het reeds een belang hield van $52 \% .{ }^{10}$ De voorgenomen transactie werd gesteund door Fininvest, het investeringsvehikel van de familie Berlusconi dat $44 \%$ van de aandelen Mediaset houdt. Een andere grootaandeelhouder van Mediaset, het Franse mediaconglomeraat Vivendi, was echter fel tegen de transactie gekant. ${ }^{11}$ Vivendi hield in eerste instantie 28,8\% van de aandelen Mediaset, als gevolg van een mislukte strategische samenwerking (dan wel vijandige overname) in $2016 .{ }^{12}$ Vivendi had deze stukken verworven nadat zij vanaf 2014, in verschillende etappes, ook al een belang van bijna $24 \%$ in Telecom Italia had opgebouwd. ${ }^{13}$ Aldus schond Vivendi beweerdelijk artikel 43 van het Italiaanse TUSMAR-besluit (hierna: TUSMAR). Op grond daarvan

6. HR 14 december 2007, ECLI:NL:HR:2007:BB3523, NJ 2008/105 m.nt. J.M.M. Maeijer; JOR 2008/11 m.nt. A. Doorman (DSM). Zie voor een uitgebreide analyse voorts J.M. de Jongh, Het loyaliteitsstemrecht. Een terreinverkenning, Ondernemingsrecht 2009/105.

7. Vgl. A.A. Bootsma, Over de toekomst van het vennootschapsrecht, in: H.J. de Kluiver (red.), 100 jaar handelsrecht. Over heden, toekomst en verleden, Zutphen: Paris 2018, p. 101-130; M. van Olffen, Nederlandse loyaliteitsaandelen met een Frans sausje, Ondernemingsrecht 2013/67.

8. Zie voor voorbeelden K.J. Bakker, Loyaliteitsregelen; lessen uit Frankrijk en Delaware, $\mathrm{MvO}$ 2019, afl. 1-2, p. 26-35; A.A. Bootsma, Loyaliteitsdividend, bijzondere stemrechtaandelen en de positie van minderheidsaandeelhouders. Midstream or IPO introduction, that's the question, $\mathrm{MvO}$ 2016, afl. 7, p. 151-160. Aan de opsommingen aldaar kon midden 2020 Campari worden toegevoegd.

9. Overigens heeft Minister van Justitie en Veiligheid Dekker zich in 2018 op het standpunt gesteld dat het gebruik van loyaliteitsaandelen ook was toegestaan zonder wettelijke basis. Vgl. Kamerstukken II 2018/19, 29752, nr. 12, p. 10.

10. Zie voor deze aankondiging www.mediaset.it/investor/documenti/2019/ notizia_9697_en.shtml/.

11. Vgl. A. Rascouet \& T. Ebhardt, Fight erupts between Bollore's Vivendi and Mediaset over merger, 2019, geraadpleegd op www.bloomberg.com/.

12. Het gerechtshof Amsterdam spreekt van een mislukte strategische samenwerking. Zie Hof Amsterdam 1 september 2020, ECLI:NL:GHAMS:2020:2379 (Mediaset), r.o. 2.6. Het Europees Hof van Justitie (zie noot 14) rept van een mislukte vijandige overname.

13. Ook bij Telecom Italia had Vivendi overigens af te rekenen met een opstandige medegrootaandeelhouder, zijnde Elliott. Vgl. G. Balp, Activist shareholders at de facto controlled companies, Brooklyn Journal of Corporate, Financial \& Commercial Law (13) 2019, p. 341-393. mogen ondernemingen die meer dan $40 \%$ van de totale omzet binnen de Italiaanse telecomsector realiseren niet meer dan $10 \%$ van de omzet binnen de Italiaanse mediamarkt realiseren. Hoewel het Europees Hof van Justitie intussen - na afloop van de hier aan de orde zijnde procedures - heeft geoordeeld dat artikel 43 TUSMAR de vrijheid van vestiging schendt, ${ }^{14}$ heeft Vivendi daaraan voorafgaand de juridische eigendom van $19 \%$ van de aandelen Mediaset ten titel van beheer overgedragen aan een vermogensbeheerder (Simon Fiduciaria). ${ }^{15}$ Ten tijde van de gang naar het gerechtshof Amsterdam hield Vivendi dus $10 \%$ van de aandelen Mediaset. Uit de tussen Vivendi en Simon Fiduciaria gesloten overeenkomst vloeit voort dat Vivendi slechts steminstructies kan geven aan Simon Fiduciaria voor zover het fundamentele onderwerpen betreft, zoals een besluit tot fusie of liquidatie van Mediaset. Ten aanzien van de overige agendapunten kan Simon Fiduciaria het stemrecht naar eigen inzicht uitoefenen. AGCOM, de Italiaanse toezichthouder op de telecomindustrie, heeft verklaard dat Vivendi met deze aanpak heeft voldaan aan de aan Vivendi gestelde eisen. ${ }^{16}$

\subsection{De door Mediaset voorgestelde loyaliteitsregeling}

Om de eerdergenoemde grensoverschrijdende fusie tussen het Italiaanse Mediaset en Mediaset España te bewerkstelligen, stelde Mediaset voor een nieuwe (Nederlandse) houdstervennootschap op te richten, Media For Europe. De (herziene) voorstellen daartoe zijn telkens goedgekeurd met ruim $75 \%$ van de stemmen op de respectievelijke algemene vergaderingen. ${ }^{17}$ Simon Fiduciaria heeft echter niet aan deze stemmingen mogen deelnemen ${ }^{18}$ - volgens Mediaset omdat Vivendi, door een gedeeltelijke instructiebevoegdheid te bedingen bij Simon Fiduciaria, niet volledig gevolg zou hebben gegeven aan het AGCOM-besluit. ${ }^{19}$ De nieuw op te richten vennootschap zou een loyaliteitsregeling kennen. Op grond daarvan zouden zittende investeerders voor ieder gewoon aandeel een additioneel aandeel A met twee extra stemmen toegekend krijgen wanneer zij daarom - voorafgaand aan de algemene vergadering waar over de herstructurering werd

14. Zie HvJ EU 3 september 2020, ECLI:EU:C:2020:627 (Mediaset).

15. Hof Amsterdam 1 september 2020, ECLI:NL:GHAMS:2020:2379 (Mediaset), r.o. 2.10.

16. Hof Amsterdam 1 september 2020, ECLI:NL:GHAMS:2020:2379 (Mediaset), r.o. 2.10

17. De beide Mediaset-vennootschappen dienden uiteraard allebei over het voorstel te stemmen. Ook is het fusievoorstel nog tussentijds aangepast om bezwaren van Vivendi te adresseren, zodat opnieuw gestemd diende te worden. Hof Amsterdam 1 september 2020, ECLI:NL:GHAMS: 2020:2379 (Mediaset), r.o. 2.12-2.13.

18. De Italiaanse rechter heeft de vordering van Vivendi tot schorsing van de fusie wegens de uitsluiting van Simon Fiduciaria meermaals afgewezen en geoordeeld dat, zelfs wanneer art. 43 TUSMAR niet in overeenstemming zou blijken met het EU-recht, de daarop gebaseerde besluiten van Mediaset geacht moeten worden geldig te blijven. Zie Hof Amsterdam 1 september 2020, ECLI:NL:GHAMS:2020:2379 (Mediaset), r.o. 2.16.2.

19. Overigens zou Vivendi, door de aandelen over te dragen aan Simon Fiduciaria, ook een standstill-bepaling uit een overeenkomst tussen Vivendi en Mediaset hebben geschonden. De vraag is dan hoe Vivendi tegelijkertijd de overeenkomst met Mediaset had moeten naleven en aan de AGCOMbeslissing had kunnen voldoen. 
besloten - hadden verzocht. ${ }^{20} \mathrm{Na}$ twee jaar zou het aandeel $\mathrm{A}$ kunnen worden geconverteerd in een aandeel $\mathrm{B}$, dat de houder daarvan recht geeft op in totaal vier extra stemmen. ${ }^{21}$ Het aandeel B zou weer drie jaar later - en dus vijf jaar na implementatie van de loyaliteitsregeling - kunnen worden omgewisseld voor een aandeel $\mathrm{C}$, dat recht geeft op in totaal negen extra stemmen. Daarmee zou het totaal uit te brengen stemmen op tien uitkomen. ${ }^{22}$ Voor zittende aandeelhouders neemt de omvang van de loyaliteitsbonus dus sterk toe in een relatief korte periode.

Overigens kende de voorgestelde governance-structuur van Media For Europe ook nog andere opvallende elementen. Met name relevant is dat het zittende bestuur Media For Europe een bindende repeterende voordracht zou kunnen doen voor nieuwe leden van het bestuur. Hoewel de algemene vergadering van Media For Europe bevoegd zou zijn een voordracht te weigeren - met een absolute meerderheid van stemmen - zou het bestuur van Media For Europe vervolgens gerechtigd zijn een nieuwe kandidaat te nomineren. ${ }^{23}$ Vanwege deze repeterende regeling zou het bestuur van Media For Europe waarschijnlijk altijd bestaan uit leden die op voordracht van Fininvest of Mediaset zijn benoemd, in ieder geval voor het overgrote deel. Zo gold dit voor het eerste post-fusiebestuur ten aanzien van dertien van de veertien leden. ${ }^{24}$

\subsection{De rechter aan zet}

Vivendi wendde zich tot de rechtbank Amsterdam - en toen zij daar nul op het rekest kreeg, het gerechtshof Amsterdam om de voorgenomen grensoverschrijdende fusie van Mediaset en Mediaset España te voorkomen. ${ }^{25}$ De uitspraken van de twee rechterlijke instanties verschillen als dag en nacht van elkaar. De rechtbank oordeelde dat loyaliteitsregelingen naar Nederlands recht zijn toegestaan, en hanteerde voor het overige een aanpak die zich het beste laat omschrijven als terughoudend. ${ }^{26}$

Het hof beoordeelde de zaak een stuk grondiger. Hoewel het gerechtshof erkende dat het gebruik van loyaliteitsregelingen is toegestaan en dat kortetermijnaandeelhouders en Fininvest niet in dezelfde positie verkeren, werd dit op zichzelf niet vol-

20. Hof Amsterdam 1 september 2020, ECLI:NL:GHAMS:2020:2379 (Mediaset), r.o. 2.14.

21. Hof Amsterdam 1 september 2020, ECLI:NL:GHAMS:2020:2379 (Mediaset), r.o. 2.14.

22. Hof Amsterdam 1 september 2020, ECLI:NL:GHAMS:2020:2379 (Mediaset), r.o. 2.14.

23. De bindende repeterende voordracht is controversieel, maar op zichzelf niet verboden. Zie Asser/Van Solinge \& Nieuwe Weme 2-IIb 2019/656-697, met verdere verwijzingen.

24. Hof Amsterdam 1 september 2020, ECLI:NL:GHAMS:2020:2379 (Mediaset), r.o. 3.15 en 3.21.1.

25. Daarnaast heeft Vivendi een aantal procedures geëntameerd in Italië (vgl noot 18) en Spanje. De Spaanse rechter heeft de invoering van de loyaliteitsregeling meermaals geschorst, in ieder geval tijdelijk. Zie laatstelijk Juzgado de lo Mercantil 28 juli 2020, ECLI:ES:JMM:2020:22A (Mediaset). Wij laten dit punt voor het vervolg goeddeels buiten beschouwing.

26. Rb. Amsterdam 26 februari 2020, ECLI:NL:RBAMS:2020:1200 (Mediaset). doende geacht om een ongelijke behandeling van aandeelhouders te rechtvaardigen. ${ }^{27}$ Aangezien artikel 2:92 lid 2 BW zijn oorsprong heeft in het Europees recht, ${ }^{28}$ dient een verschil in behandeling (1) objectief gerechtvaardigd, (2) adequaat, (3) noodzakelijk en (4) proportioneel te zijn. ${ }^{29}$ Het creëren van een stabiele basis van investeerders voor de lange termijn werd in beginsel erkend als een legitiem doel. ${ }^{30}$ Het hof oordeelde echter dat aan de vereisten 2, 3 en 4 niet was voldaan, omdat de loyaliteitsregeling en de repeterende bindende voordracht, in onderlinge samenhang bezien, Fininvest in staat stelden volledige en eeuwigdurende controle uit te oefenen. ${ }^{31}$ Ook toonde het hof zich erg kritisch ten aanzien van twee deelaspecten van de grensoverschrijdende fusie.

Allereerst zou het hanteren van een high/low-benadering, waarin aan alle aandeelhouders direct aanvullende loyaliteitsstemrechten worden toegekend in plaats van dat voor alle aandeelhouders een ingroeiperiode geldt (low/high), ${ }^{32}$ Fininvest op voorzienbare wijze bevoordelen. ${ }^{33}$ De invloed van Fininvest zou immers direct en ogenblikkelijk na voltooiing van de grensoverschrijdende fusie toenemen. Van de aandelen die niet door Fininvest, Vivendi of Simon Fiduciaria werden gehouden, is slechts 6\% aangemeld voor de loyaliteitsregeling. ${ }^{34} \mathrm{Bij}$ het verwerpen van een high/low-benadering woog het hof ook mee dat slechts $10 \%$ van de niet met Fininvest verbonden aandeelhouders voor de grensoverschrijdende fusie had gestemd. ${ }^{35}$ Hoewel de observaties van het hof geen defini-

27. Hof Amsterdam 1 september 2020, ECLI:NL:GHAMS:2020:2379 (Mediaset), r.o. 3.18.

28. Vgl. noot 4 .

29. Zie in vergelijkbare zin, maar enigszins anders HR 31 december 1993, ECLI:NL:HR:1993:ZC1212 (Verenigde Bootlieden).

30. Hof Amsterdam 1 september 2020, ECLI:NL:GHAMS:2020:2379 (Mediaset), r.o. 3.20.

31. Hof Amsterdam 1 september 2020, ECLI:NL:GHAMS:2020:2379 (Mediaset), r.o. 3.20-3.21.2. Er was met andere woorden sprake van een mismatch tussen het gestelde en het feitelijke doel van de loyaliteitsregeling. Overigens was er naar het oordeel van het hof ook nog een andere reden om de grensoverschrijdende fusie niet door te laten gaan. Die vloeide voort uit het feit dat het fusievoorstel van 26 maart 2020 van MFE slechts voorzien was van accountantsverklaringen per 18 juni 2019. Een door de accountant opgesteld addendum per 24 maart 2020 bood geen soelaas, omdat dit enkel zag op de situatie per 18 juni 2019 en niet op de ontwikkelingen daarna. Vgl. Hof Amsterdam 1 september 2020, ECLI:NL:GHAMS:2020:2379 (Mediaset), r.o. 2.17. Wij laten dit punt verder buiten beschouwing.

32. Hof Amsterdam 1 september 2020, ECLI:NL:GHAMS:2020:2379 (Mediaset), r.o. 3.21.3. Zie over het onderscheid tussen high/low-en low/ high-loyaliteitsstructuren P.H. Edelman, W. Jiang \& R.S. Thomas, Will tenure voting give corporate managers lifetime tenure?, Texas Law Review (97) 2019, p. 991-1030; D.J. Berger, S.M. Davidoff \& A.J. Benjamin, Tenure voting and the U.S. public company, The Business Lawyer (72) 2017, p. 295-327; L.L. Dallas \& J.M. Barry, Long-term shareholders and time-phased voting, Delaware Journal of Corporate Law (40) 2015, p. 541-646.

33. Aangezien Vivendi ten gevolge van de TUSMAR-problematiek nog maar $10 \%$ van de aandelen Mediaset hield (en Fininvest 44\%), zou door het onmiddellijk ingaan van de loyaliteitsregeling Fininvest direct een exponentieel groter aantal stemmen kunnen uitbrengen.

34. Hof Amsterdam 1 september 2020, ECLI:NL:GHAMS:2020:2379 (Mediaset), r.o. 3.17.1.

35. Hof Amsterdam 1 september 2020, ECLI:NL:GHAMS:2020:2379 (Mediaset), r.o. 3.21.5. 


\section{Maandblad \\ Ondernemingsrecht}

tief uitsluitsel bieden, zou de vraag kunnen opkomen of bij de keuze tussen een high/low- en een low/high-structuur gekeken moet worden naar de spreiding van het aandelenbezit, waarbij - de lijn van het hof volgend - in geval van een geconcentreerd bezit een low/high-structuur meer in de rede zou kunnen liggen. Low/high-structuren kennen echter ook nadelen. ${ }^{36}$ Daarnaast zou, de redenering van het hof volgend, de vraag post kunnen vatten of loyaliteitsstructuren die worden ingevoerd bij vennootschappen die reeds aan de beurs zijn genoteerd (midstream), onderworpen dienen te worden aan een stemming van uitsluitend minderheidsaandeelhouders (majority-of-the-minority vote), dat wil zeggen zonder dat een eventuele controlerend aandeelhouder daaraan kan deelnemen. Een dergelijke benadering is gangbaar naar Amerikaans recht. ${ }^{37}$ Wij zien op dit moment onvoldoende aanleiding voor zo'n aanpak naar Nederlands recht.

Naast de kritiek op de high/low-benadering verwierp het hof het argument dat de loyaliteitsregeling Mediaset in staat zou stellen aandeelhouders aan te trekken met het oog op de lange termijn. ${ }^{38}$ De loyaliteitsregeling zou nieuwe aandeelhouders juist op achterstand zetten. Hoewel de regeling het inderdaad mogelijk zou maken om aanvullend kapitaal op te halen zonder de invloed van zittende investeerders te verwateren, werd dit voordeel geacht toe te vallen aan de controlerend aandeelhouder, en niet aan de vennootschap. ${ }^{39}$

\subsection{Waardering}

Wij kunnen ons goed vinden in de uitkomst van de zaak bij het hof, niet alleen vanwege het bovenstaande, maar ook om een reden die hierboven nog niet aan de orde is gekomen.

De creatie van loyaliteitsregelingen wordt vaak zo gestructureerd dat zij geen aanleiding vormt een verplicht bod uit te brengen wegens het verwerven van overwegende zeggenschap. Voor dat concept wordt, zowel in de wet als in de statuten zoals die door Mediaset waren voorgesteld, aangeknoopt bij het slechten van de 30\%-grens. In het geval van Mediaset gold dat Fininvest reeds een kapitaalbelang van 30\% hield en om die reden was vrijgesteld van het uitbrengen van een verplicht bod. ${ }^{40}$ Voor Vivendi lagen de zaken echter anders. Wanneer

36. Institutionele beleggers kiezen er vaak voor hun aandelen niet aan te melden voor een loyaliteitsregeling, onder meer omdat dit de liquiditeit ervan vermindert. Vgl. J. Bos, Ik heb grote moeite met extra stemrecht of dividend voor langetermijnbeleggers, Het Financieele Dagblad 26 mei 2015. Bij een high/low-structuur kunnen institutionele partijen in ieder geval direct hun (aanvullende) stemrechten uitoefenen.

37. Vgl. (in algemene zin) Kahn v. M\&F Worldwide, 88 A.3d 635 (Del. 2014); zie ook (specifiek inzake dual class-situaties) IRA Trust FBO Bobbie Ahmed v. Crane, No. 12742-CB (Del. Ch. 2017). Zie hierover I. Fiegenbaum, The geography of MFW-land, Delaware Journal of Corporate Law (41) 2017, p. 763-802.

38. Hof Amsterdam 1 september 2020, ECLI:NL:GHAMS:2020:2379 (Mediaset), r.o. 3.21.6.

39. Hof Amsterdam 1 september 2020, ECLI:NL:GHAMS:2020:2379 (Mediaset), r.o. 3.21.7.

40. Zie art. 1:1 jo. art. 5:70 Wft. Er is immers geen verkrijging van overwegende zeggenschap; vgl. Kamerstukken II 2005/06, 30419, nr. 3, p. $25-26$.
(1) de loyaliteitsregeling zou worden ingevoerd en (2) artikel 43 TUSMAR inderdaad buiten werking zou worden gesteld door het Europees Hof van Justitie, zou het kapitaalbelang van Vivendi van $28,8 \%$ in Mediaset resulteren in een stembelang groter dan 30\%. Daarmee zou Vivendi zijn gedwongen een verplicht bod op Mediaset uit te brengen. Het enige alternatief voor Vivendi zou daarmee zijn om af te zien van deelname aan de loyaliteitsregeling, met als gevolg dat haar invloed zou verwateren. De loyaliteitsregeling werd daarmee wat ons betreft voor oneigenlijke doeleinden gebruikt, namelijk niet voor het creëren van een stabiele basis van langetermijnaandeelhouders, maar de facto om Vivendi klem te zetten. Fininvest daarentegen zou haar belang in Mediaset na verloop van slechts een relatief korte termijn gedeeltelijk te gelde kunnen maken zonder aan invloed te hoeven inboeten. ${ }^{41}$

De uitspraak van het hof creëert tegelijkertijd wel enige onduidelijkheid rondom de vraag welke multiplier naar Nederlands recht is toegestaan bij een midstream-invoering van een loyaliteitsregeling. Het hof overweegt dat een 'vermenigvuldigingsfactor van vijf vooralsnog disproportioneel' is in verhouding tot het nagestreefde doel van langetermijnaandeelhouderschap. ${ }^{42}$ Dat roept de vraag op of er omstandigheden denkbaar zijn waarin een multiplier van vijf wel mogelijk is, of dat in de regel van een lager getal uitgegaan moet worden - loyaliteitsstructuren worden soms geassocieerd met één aanvullende stem per aandeel ${ }^{43}$ - en dat afwijking naar boven slechts bij wijze van uitzondering toegestaan is. ${ }^{44}$ Het is niet volledig helder welke aanpak nog (net) acceptabel is en welke niet meer. In die zin leidt de uitspraak van het hof ook tot rechtsonzekerheid.

\section{De RNA-uitspraak van de OK}

\subsection{Inleiding}

De RNA-zaak is met name bekend vanwege het alomtegenwoordige kader dat de Hoge Raad formuleerde voor het gebruik van beschermingsmaatregelen. ${ }^{45}$ Ook de uitspraak van de $\mathrm{OK}$ bevat echter veel moois en biedt aanleiding om een

41. Vgl. Hof Amsterdam 1 september 2020, ECLI:NL:GHAMS:2020:2379 (Mediaset), r.o. 2.16, alwaar een in een Spaanse procedure ingebracht rapport van Banco Santander wordt aangehaald dat Fininvest vijf jaar na implementatie van de loyaliteitsregeling, door het gebruik van de aandelen C, 56,35\% van de stemmen zal kunnen uitoefenen.

42. Hof Amsterdam 1 september 2020, ECLI:NL:GHAMS:2020:2379 (Mediaset), r.o. 3.21.3.

43. Dat is bijv. het geval in Belgie, waar het ondernemingsrecht in 2019 grondig werd herzien. Vgl. J. Delvoie \& S. Declercq, De invoering van meervoudig stemrecht en loyauteitsstemrecht in bestaande vennootschappen, Tijdschrift voor Rechtspersoon en Vennootschap - Revue pratique des sociétés 2019, p. 129.

44. Te sterk naar onze smaak Leijten in zijn annotatie in JOR 2020/279 bij de onderhavige uitspraak, waar hij in nr. 17 concludeert dat er in beginsel geen goede redenen zijn om bij een vennootschap met geconcentreerd aandelenbezit een loyaliteitsregeling in te voeren.

45. Zie HR 18 april 2003, ECLI:NL:HR:2003:AF2161, NJ 2003/286 m.nt J.M.M. Maeijer; JOR 2003/110 m.nt. J.M. Blanco Fernández (RNA), waarover bijv. Asser/Van Solinge \& Nieuwe Weme 2-IIb 2019/572-575, Asser/Van Olffen \& Rensen 2-IIa 2019/336. 
zekere parallel te trekken tussen het effect van een loyaliteitsregeling en de grenzen waarbinnen een grootaandeelhouder zich in redelijkheid dient te bewegen. ${ }^{46}$

In augustus 2001 verkocht Stichting Pensioenfonds ABP een deel van haar belang, namelijk 23,9\%, in beleggingsmaatschappij met veranderlijk kapitaal RNA. ${ }^{47}$ De koper was Westfield, een Australische vastgoedbeheerder. Toen de samenwerkingsgesprekken tussen RNA en Westfield op niets uitliepen, verzocht Westfield RNA een buitengewone algemene vergadering bijeen te roepen, waarin zou moeten worden besloten over ontslag van bestuurders en commissarissen van RNA. RNA heeft dit verzoek afgewezen. Vanwege het aandeelhoudersabsenteïsme was de verwachting dat Westfield de besluitvorming in de algemene vergadering naar haar hand zou kunnen zetten. RNA heeft Westfield uitgenodigd om een volledig bod te doen op alle uitstaande aandelen, maar Westfield ging daar niet op in. Kort daarop heeft RNA zowel aandelen uitgegeven aan Stichting RNA alsmede een optie toegekend waardoor deze stichting tot een maximum van $41,2 \%$ van het totaal geplaatste kapitaal in handen zou kunnen krijgen. ${ }^{48}$ Westfield diende daarop een verzoek in bij de OK tot het gelasten van een enquête. De OK overwoog in haar eerste beschikking in deze zaak:

'3.18 Tegen die achtergrond staat het dan ook het bestuur van de vennootschap vrij maatregelen te nemen teneinde te voorkomen dat een (minderheids)aandeelhouder ten aanzien van wie in redelijkheid valt te betwijfelen of hij handelt in overeenstemming met voormelde $\left[{ }^{49} ; \mathrm{HVvD} \&\right.$ TK] norm - bijvoorbeeld doordien de door hem uit te oefenen zeggenschap op onaanvaardbare wijze wordt aangewend te zijnen faveure en ten nadele van de overige aandeelhouders, of een overwegende mate van zeggenschap jegens de overige aandeelhouders in redelijkheid slechts aanvaardbaar is te achten indien dezen het aanbod wordt gedaan hun aandelen aan hem aan te bieden - een overwegende of belangrijke mate van zeggenschap verkrijgt.

3.19 RNA heeft omstandig betoogd dat Westfield in strijd handelt met voormeld uitgangspunt, meer in het bijzonder doordat Westfield - die, hoezeer minderheidsaandeelhou-

46. Hof Amsterdam 22 maart 2002, ECLI:NL:GHAMS:2002:AE0542, Ondernemingsrecht 2002/25 m.nt. G.N.H. Kemperink (RNA).

47. De feiten zijn kenbaar uit HR 18 april 2003, ECLI:NL:HR: 2003:AF2161 (RNA), r.o. 3.1.

48. Vgl. over deze ontwikkelingen ook B. Winters, E.W.A. van de Weert \& C.L. de Bel, De afloop van de sluipoverval van Westfield op RNA, V\&O 2003, afl. 9, p. 134-138.

49. Dit is de norm dat ingevolge art. 2:8 BW de verwerver van een pakket aandelen als behoorlijk aandeelhouder in zijn handelen niet alleen zijn eigen belangen, maar ook de belangen van de vennootschap in al haar facetten en de belangen van de bij de vennootschap betrokken personen (in dit specifieke geval met name de belangen van de overige aandeelhouders) dient te betrekken. Zie Hof Amsterdam 22 maart 2002, ECLI:NL:GHAMS:2002:AE0542, Ondernemingsrecht 2002/25 m.nt. G.N.H. Kemperink (RNA), r.o. 3.17. der, de facto de beslissende zeggenschap in de Algemene Vergadering van Aandeelhouders kan uitoefenen en die niet voornemens is aan de overige aandeelhouders een openbaar bod te doen - een plan heeft gepresenteerd dat bij uitvoering ervan zal leiden tot - kort gezegd - hoge kosten voor RNA, Westfield onevenredig zal bevoordelen, de overige aandeelhouders schade zal toebrengen, belangenvermenging tot gevolg heeft en RNA en Westfield in een rechtstreekse concurrentiepositie plaatst, zulks terwijl Westfield in beide posities de zeggenschap zal hebben, waardoor valt aan te nemen dat Westfield haar belang zal doen prevaleren boven het belang van RNA en de - overige - aandeelhouders van RNA. ${ }^{50}$

\subsection{Analyse}

In de RNA-zaak bracht Westfield geen openbaar bod uit omdat zij, vanwege het absenteïsme van aandeelhouders op algemene vergaderingen, met haar belang van $23,9 \%$ een doorslaggevende stem had. ${ }^{51}$ Dit in combinatie met de feiten dat (1) Westfield een concurrent was van RNA en (2) Westfield voornemens was RNA een plan te laten implementeren dat zou leiden tot hoge kosten voor RNA ten faveure van Westfield, leidde tot het oordeel dat het RNA vrijstond maatregelen te nemen om de invloed van Westfield te beperken (met alle daarbij aangegeven beperkingen). ${ }^{52} \mathrm{De} \mathrm{OK}$ woog bij dit oordeel mee dat een dergelijk handelen door een grootaandeelhouder jegens overige aandeelhouders slechts aanvaardbaar geacht kan worden indien de grootaandeelhouder aanbiedt om die andere aandeelhouders uit te kopen. ${ }^{53}$

Bij de beantwoording van de vraag of een loyaliteitsregeling met een bepaalde multiplier een al of niet te rechtvaardigen schending van het gelijkheidsbeginsel inhoudt, kan betekenis worden toegekend aan de vraag in hoeverre (1) bestaande minderheidsaandeelhouders worden benadeeld en (2) het aantrekken van nieuw kapitaal wordt tegengegaan. Aan het eerste aspect heeft het hof in de Mediaset-uitspraak uitvoerig aandacht besteed. ${ }^{54} \mathrm{Op}$ het tweede aspect wordt, afgezien van de overweging dat nieuwe beleggers door de loyaliteitsregeling op achterstand worden gezet, ${ }^{55}$ nauwelijks ingegaan. Gegeven de exponentiële vermenigvuldiging van de stemrechten van Fininvest en het risico dat nieuwe grootaandeelhouders die gebruik zouden willen maken van de (voorgestelde) loyaliteits-

50. Hof Amsterdam 22 maart 2002, ECLI:NL:GHAMS:2002:AE0542, Ondernemingsrecht 2002/25 m.nt. G.N.H. Kemperink (RNA), r.o. 3.18-3.19.

51. Zie over chronisch absenteïsme onder aandeelhouders aan het begin van deze eeuw bijv. G.T.M.J. Raaijmakers, Beleggers, aandeelhouders en de AVA, Ondernemingsrecht 2005/38.

52. Zie over deze beperkingen onder meer Hof Amsterdam 22 maart 2002, ECLI:NL:GHAMS:2002:AE0542, Ondernemingsrecht 2002/25 m.nt. G.N.H. Kemperink (RNA), r.o. 3.7-3.8.

53. Hof Amsterdam 22 maart 2002, ECLI:NL:GHAMS:2002:AE0542, Ondernemingsrecht 2002/25 m.nt. G.N.H. Kemperink (RNA), r.o. 3.15 .

54. Hof Amsterdam 1 september 2020, ECLI:NL:GHAMS:2020:2379 (Mediaset), r.o. 3.15-3.21.5.

55. Hof Amsterdam 1 september 2020, ECLI:NL:GHAMS:2020:2379 (Mediaset), r.o. 3.21.6-3.21.7. 


\section{Maandblad}

regeling zouden lopen op het moeten uitbrengen van een verplicht bod, werd de kans dat Vivendi haar belang in Mediaset tegen een goede prijs zou kunnen verkopen, verkleind. ${ }^{56}$ De vraag of de voorgestelde loyaliteitsregeling het aantrekken van nieuw kapitaal zou bevorderen, zou derhalve naar alle waarschijnlijkheid ook ontkennend beantwoord moeten worden. Immers, als een investeerder op termijn geen goede exit zal kunnen realiseren, waarom zou deze dan überhaupt kapitaal ter beschikking willen stellen ${ }^{57}$

Naar onze mening zou het bestuur van een vennootschap die overweegt om een loyaliteitsregeling in te voeren, in het kader van de afweging of deze regeling voldoet aan de eisen van proportionaliteit, onder meer expliciet aandacht moeten besteden aan de vraag of, en zo ja, in hoeverre de loyaliteitsregeling het in de toekomst aantrekken van nieuw kapitaal respectievelijk het uitkeren van ingelegd kapitaal bevordert dan wel verhindert. Dat zal uiteraard afhangen van verschillende karakteristieken van de voorgestelde regeling. In de ideale wereld wordt immers een balans gevonden tussen het creëren of bevorderen van een stabiele aandeelhoudersbasis en het aantrekken van nieuw kapitaal. Deze afweging kan mogelijk ook een begin van een antwoord opleveren op de eerder opgeworpen vraag in hoeverre een bepaalde multiplier al of niet gerechtvaardigd is.

\section{Conclusie}

In dit artikel bespraken wij de Mediaset-uitspraken van de rechtbank Amsterdam en het gerechtshof Amsterdam, voor zover deze betrekking hadden op loyaliteitsaandelen. Hoewel het hof het wat ons betreft bij het juiste eind had, is de onduidelijkheid rondom de eisen die aan de invoering van een loyaliteitsregeling gesteld worden met diens uitspraak wel toegenomen. Met dit artikel hebben wij een voorzet gedaan om deze onduidelijkheid te verminderen.

Ondertussen is de wetgever nog steeds aan het broeden op de modernisering van het NV-recht. Wij hopen dat deze uitspraak en de situaties die daaruit voortvloeien een stimulans vormen om dat proces verder ter hand te nemen.

56. Een gedwongen verkoop op korte termijn leidt veelal tot een zekere strafkorting. Vgl. T.C. Pulvino, Do asset fire sales exist? An empirical investigation of commercial aircraft transactions, Journal of Finance (53) 1998, p. 939-978; zie ook A. Shleifer \& R.W. Vishny, Liquidation values and debt capacity: A market equilibrium approach, Journal of Finance (47) 1992, p. 1343-1366.

57. Een grootaandeelhouder die zijn stukken op de open markt verkoopt, lijdt daarop niet zelden flink verlies. Vgl. A. Edmans, Blockholders and corporate governance, Annual Review of Financial Economics (6) 2014, p. 23-50. 